\title{
Depression in Dyslexic Children Attending Specialized Schools: A Case of Switzerland
}

\author{
Tamara Leonova \\ University of Nancy,
}

France

\section{Introduction}

Dyslexia (specific reading disability) is a common, cognitively and behaviorally heterogeneous developmental condition, characterized primarily by a severe difficulty in mastering reading despite average intelligence and adequate education (Grigorenko, 2001). A recent epidemiological study in France found $3.5 \%$ of the students in 2nd grade (CE1) were dyslexic (Billard et al., 2007).

According to an INSERM report (Expertise de l'INSERM, p. 162), even though dyslexia is the most studied of the learning disabilities, the scientific community knows relatively little about it, and most of this knowledge comes from studies done about the cognitive, social and emotional development of English-speaking dyslexics. The depressive symptoms of French-speaking children and adolescents suffering from reading disabilities have not been empirically studied.

In general, learning disabilities (LD) increase the risk of depression. According to a literature review based on research conducted between 1980 and 2003, 16 out of 24 studies (67\%) found that the level of depression of those suffering from LD was significantly higher than those without LD (Sideridis, 2006). New theoretical models have been developed to explain depression in students with LD (e.g., Sideridis, 2005, 2007). In a review of publications on the links between literacy and mental disorders, Maughan and Carroll (2006) concluded "literacy problems are associated with increased risks of both externalizing and internalizing disorders in childhood" (p. 350). They also highlighted the inconsistent results found when trying to associate depression and dyslexia.

Researchers and practitioners have focused on depression ${ }^{1}$ since it is one of the major risk factors in youth suicide. Several publications on dyslexia and schooling of dyslexic children mention that they are susceptible to developing depression (Hulme \& Snowling, 1997; Reid \& Fawcett, 2004; Hunter-Carsch \& Herrington, 2001; Hunter-Carsch, 2001; Scott, 2004).

Researchers in the UK have been investigating depression and anxiety in children with learning disabilities for quite some time (Brumback, Dietz-Schmidt, \& Weinberg, 1977;

\footnotetext{
${ }^{1}$ A single definition for depression has not been found. We use the terms depression, depressive mood, depressive disorder and depressive symptoms interchangeably. In the studies on depression and dyslexia presented in the introduction and in our study, the objective of the researchers is not to diagnose depression but rather to evaluate the level of depressive symptoms.
} 
Stevenson \& Romney, 1984), whereas in France little research on the problem has been conducted. We therefore chose to investigate the level of depressive symptoms in French speaking dyslexic students and to examine the prevalence of children with clinical symptoms of depression. After presenting the results of research on depression in dyslexic children and adolescents, we will briefly discuss the limitations of generalizing research conducted in English, dominant in this field, when extended to a sample of French-speaking dyslexic students. The second part of the chapter will present a study exploring depressive symptoms in French-speaking students.

\section{Depression in children and adolescents with dyslexia}

In the first decade of the 21st century, researchers have become increasingly interested in depression in children and adolescents with dyslexia (e.g. Carroll, Maughan, Goodman, \& Meltzer, 2005; Maughan, Rowe, Loeber, \& Stouthamer-Loeber, 2003; Miller, Hynd, \& Miller, 2005; Willcutt \& Pennington, 2000), as well as adults with dyslexia (Alexander-Passe, 2006). Nonetheless, the first studies on the internalized problems and depression in people with specific reading disabilities were conducted during 1980s and also at the beginning of the 1990s (e.g. Casey, Levy, Brown, \& Brooksgunn, 1992; Kline, 1986). Results showed that children with dyslexia were more anxious and less happy than peers without dyslexia, despite their coming from families with high socio-economic levels, with parents having strong educational backgrounds and being well informed about dyslexia (Casey, Levy, Brown, \& Brooksgunn, 1992). This study compared 28 dyslexic children with 39 children in a control group and was based of evaluations by parents.

A few years later the results of another study helped to improve our understanding of depression in people with dyslexia. By comparing depression measurements in children, adolescents and adults with dyslexia in a cross-sectional study, Boetsch, Green and Pennington (1996) showed that children and adolescents had high levels of depression compared to the control group. On the other hand, in dyslexic adults the degree of depressive symptoms was comparable to the control group. It therefore seems that people with dyslexia feel less depressed and happier as they grow up.

Willcutt and Pennington (2000) in a study comparing behavior problems in twins with and without dyslexia found that girls had higher levels of depression than boys. Reading disability and depression were specifically associated only for girls. These results support those found by Dekker, Ferdinand, van Lang, Bongers, van der Ende and Verhulst (2007) on the general population and the critical review of literature by Piccinelli and Wilkinson (2000) that found that girls suffered from higher levels of depression than boys.

Research by Maughan and al. (2003) based on results from a longitudinal study with three periods of internalized and externalized problems of dyslexic boys between 9 and 15 years old found that the percentage of boys labeled as being depressed decreased with age: $13.4 \%$ at 7 years old, $7.1 \%$ at 10 and $2.5 \%$ at 13 . They suggested that reading disabilities were strongly associated with short-term depression, but that there was no increased risk of longterm depression.

In another study in the UK, Carroll, Maughan, Goodman, \& Meltzer (2005) evaluated different internal and external problems in 68 girls and 221 boys from 11 to 15 years old with 
specific reading disabilities. Reading disabilities were associated with depressive mood in self-evaluation scores of adolescents. Although there was no association between dyslexia and depressive mood in girls, there was a strong correlation between depression and dyslexia in boys, especially younger ones. Carroll et al., thus, concluded that specific reading disabilities were associated with all the major psychiatric diagnosis except with depression where no relationship was found. No link between dyslexia and depression was found (Carroll et al., 2005).

Results from research by Miller, Hynd and Miller (2005) conducted in the USA, based on a different methodology with three sources of information, were similar to those of Carroll et al. (2005). These researchers did not test for the impact of gender due to sample size $(\mathrm{N}=79$ with 20 people with dyslexia and 59 without, from 6 to 16 years old). Instead they used three sources of information (i.e., parents, children, and teachers), and two types of diagnosis for dyslexia as well as measuring depression, anxiety and somatic symptoms. Since no significant difference in level of depressive symptoms was found between dyslexic children and the control group, when comparing depressive symptoms according to information source, type of dyslexic diagnosis or measurement, Miller et al. concluded there was no significant difference between the two groups. For dyslexic children and adolescents all the depression scores were within the norms and no age effect was found.

In a more recent study conducted by Alexander-Passe (2006), the depression scores of 19 dyslexic adolescents ( 12 boys and 7 girls from 14 to 16 years old) were compared with scores of different groups of subjects from other studies using the same measurements (i.e., Beck Depression Inventory-II; Beck, Steer, \& Brown, 1996). These girls seemed to have a moderate level of depression, whereas boys had a low level. The overall depression scores of dyslexic adolescents were slightly higher than the norm of students without dyslexia, though not reaching clinical levels.

What conclusions can be drawn from these studies? First of all, it is difficult to compare these studies as they use different methodologies, samples and measurement tools. Secondly, when control groups were used, certain researchers found the differences significant (e.g. Casey et al., 1992), whereas others considered depression scores of dyslexic students to be similar to those of the control group (e.g. Boetsch et al., 1996; Miller et al., 2005; Alexander-Passe, 2006) or that only girls' scores were different (e.g. Willcutt \& Pennington, 2000). Thirdly, only three studies namely, Alexander-Passe (2006), Miller and al. (2005) and Willcutt \& Pennington (2000) refer to normal depression scores to evaluate levels of depression in the studied samples. Therefore, though problems of depression seem to be associated with reading disabilities, particularly with girls, more systematic studies using same methodologies, similar samples and same measurement protocols are needed to conclusively evaluate the risks of depression with dyslexia.

Languages' alphabetical systems differ in their degree of grapheme-phoneme correspondence transparency. Some languages have systems that are considered to be transparent as they transcribe surface phonology with relative fidelity. Others have opaque spelling; their graphicphonologic encoding rules are inconsistent (Grigorenko, 2001; Ziegler \& Montant, 2005).

Research on reading and writing acquisition in French has found that French is in between these two groups of languages. French is closer to transparent languages when being read. On the other hand, phoneme-grapheme relationships in French are much more irregular 
(Peereman \& Content, 1999; Sprenger-Charolles \& Serniclaes, 2003; Ziegler, Jacobs, \& Stone, 1996). As a result, when learning spelling, French is closer to opaque or irregular languages like English (Ziegler \& Montant, 2005). Since French spelling is more regular than English, French dyslexics have less problems with reading skills than English ones do. French dyslexic reading disabilities should have less impact on other school learning than for English speakers, and thus one might argue that there should be less symptoms of depression. English-speaking dyslexics seem be the most linguistically and thus socially disadvantaged. Applying generalized findings about the psychological well-being of this group to other groups with linguistic advantages would be unjustified. We can conclude that in the case of dyslexia, the language spoken by a dyslexic person must be taken into consideration when evaluating their difficulties.

Language regularity is not the only factor limiting the external validity of findings with English-speakers. Other factors, part of cultural context, are also pertinent as they affect the quality and quantity of difficulties that dyslexics confront. Some studies have highlighted the effect of school choice on dyslexic child self-esteem (Burden, 2005; Humphrey, 2002; Thomson, 1990) and on general psychological functioning of children with learning disabilities (Wiener \& Tardif, 2004). Even if the findings of these studies are sometimes contradictory or difficult to interpret due to methodology (e.g., no control group or inadequate sample selection) they still suggest that school choice influences the psychological well-being of dyslexic children.

We hypothesize therefore both that language characteristics (opaque verses transparent spelling) influence the visibility of dyslexia in a person and that educational systems, in particular specialized ones, affect a student's psychological well-being. Since educational systems in different countries, attitudes towards dyslexia and knowledge about this specific learning disability in different cultures are quite different, generalizing findings from research on English-speakers or other countries or languages would be unjustifiable.

\section{Objectives}

Our study has two objectives: 1) examine the level of depressive symptoms in Frenchspeaking dyslexic children in a specialized school in French-speaking Switzerland and compare them with children without dyslexia, and 2) evaluate the level of depressive symptoms in the two populations. Little international research has been conducted on this type of specialized schooling for dyslexic children.

\section{Method}

\subsection{Participants}

Sixty-six children participated in the study: 35 dyslexic children in a specialized school and 31 children without dyslexia. All were from Fribourg canton in Switzerland and had French as their maternal and only language spoken at home. They all had started school at age 5 to 62 , had traditional schooling, no serious neurological, sight or hearing problems, took no regular medication, nor had any oral language problems, anxiety or depressive disorders.

\footnotetext{
${ }^{2}$ In Fribourg canton, school is not obligatory for children when they are 5 years old. Most children start primary school at age 6 .
} 
This information was obtained from parents' responses to a questionnaire designed for this study. The socio-demographic characteristics of the families are presented in Table 1. Informed and written consent was obtained from subjects' parents.

\subsubsection{Selection of the dyslexic children}

35 (13 female and 22 male) dyslexic children $(\mathrm{M}=10$ years 7 months, $\mathrm{SD}=1.49$, from 8 years 2 months to 14 years 10 months) took part in the study. All had been diagnosed as dyslexic by age 8 - 9 years by the canton school system. All had global IQs greater than 80 (IQ scores were indicated in their school files). All the children had remedial speech therapy three times per week during the school year (average weekly duration: one and half hours) and their reading skills were between 1 year 8 months and 4 years 9 months behind, according to Test de l'Alouette. Their hyperactivity scores in SDQ (Goodman, 2001) were less than 6 (within the normal range).

Age chosen for the sample is justified since obligatory schooling in Switzerland is from 6 to 15 years old. As a result, one of dyslexia's known characteristics, being 2 years behind in reading skills, can be found in 8 year old children.

\subsubsection{Selection of children in the control group}

The children in the control group were all recruited from French-speaking schools in Fribourg canton. 31 (16 female and 15 male) children $(\mathrm{M}=11$ years 2 months, $\mathrm{SD}=2.46$, from 8 years 4 months to 15 years 1 month) participated in the study. All children had their parents' consent. To collect information about families and their child's development, parents also completed a questionnaire identical to the one completed for dyslexic children. Dyslexic and control groups were matched for age and gender as best possible. The sociodemographic characteristics of the families are presented in Table 1.

Data analysis suggests that more mothers finished secondary school in the control group than did mothers of dyslexic children. More mothers of dyslexic children have manual professions. Significantly more mothers of the control group are housewives. Overall, mothers of children without dyslexia had higher levels of schooling, and as housewives, they had more opportunity to take care of the children and better help them with their schoolwork.

We were not allowed to give IQ tests to the control group: according to the school, all children in the normal school system had normal IQs. The children in the control group took a reading test (i.e. Test de l'Alouette) to test the reading skills, as well as Children's Depression Inventory by Kovacs (2001). The Test de l'Alouette results confirmed that children in the control group had normal reading skills for their age. Since students' schedules were already quite busy, the school did not authorize us to diagnose for dyslexia using ODEDYS (Outil de Dépistage des Dyslexies) tests.

\subsection{Procedure}

During the first step, we tested to confirm that the children in the dyslexic group were properly diagnosed as dyslexic. Reading level was assessed using Test de l'Alouette (Lefevrais, 1967), a standard reading achievement test widely used with French children. A 
meaningful passage was presented, and the participant had to read it aloud (within a 3-min time limit). Time (in sec/syllable) and accuracy (number of errors, adjusted for the amount of text read) were measured.

We used ODEDYS (2002), which offers a number of tasks designed to evaluate skills that are frequently limited or deficient in dyslexic children. The scores for each task in ODEDYS are presented in Table 2.

\begin{tabular}{llcc}
\hline & & $\begin{array}{c}\text { Dyslexic children } \\
(n=35)\end{array}$ & $\begin{array}{c}\text { Control group } \\
(n=31)\end{array}$ \\
\hline Age & Girls & $\begin{array}{c}M=10.7 \text { years } \\
S D=1.49\end{array}$ & $\begin{array}{c}M=11.2 \text { years } \\
S D=2.46\end{array}$ \\
\hline Sex & Boys & $37 \mathrm{a}$ & 52 \\
Mother's level of & Primary & 63 & 48 \\
studies & Secondary & 5.4 & 3.2 \\
& Higher education & $43.3 \mathrm{~b}$ & $58.1^{\mathrm{b}}$ \\
& No response & 45.9 & 38.7 \\
& & 5.4 & - \\
Mother's profession & Manual & & $12.9 \mathrm{c}$ \\
& Non manual & $24.3 \mathrm{c}$ & 67.7 \\
& Housewife & 64.9 & $19.4^{\mathrm{d}}$ \\
& No response & $5.4^{\mathrm{d}}$ & - \\
& & 5.4 & 41.9 \\
& Manual & & 58.1 \\
& Non manual & 48.7 & - \\
\hline
\end{tabular}

a \%

${ }^{\mathrm{b}} p<.001\left(\chi^{2}(2, N=62)=17.94\right.$

c $p<.05\left(\chi^{2}(2, N=62)=3.90\right.$

d $p<.001\left(\chi^{2}(2, N=62)=23.09\right.$

Table 1. Demographic characteristics of the sample

The second step was to evaluate children's depression.

All of the evaluations took place individually in a room set aside by the corresponding school for the researchers. To insure that dyslexic students' reading difficulties did not interfere with their understanding the questionnaire, each item of the CDI (Children's Depression Inventory, Kovacs, 2001) was read aloud to the dyslexic child, after which the child indicated the sentence that best described himself/herself. The same procedure was followed with the control group.

At the end of the session each student was thanked and received a candy. 
ODEDYS tasks $\quad M \quad S D$

\begin{tabular}{lcc} 
Number of irregular words correctly read & $6.61(20) \mathrm{a}$ & 4.66 \\
Time taken for task (sec) & 51.52 & 25.85 \\
Number of regular words correctly read & $14.39(20)$ & 4.42 \\
Time taken for task (sec) & 44.85 & 24.32 \\
Number of pseudo words correctly read & $12.06(20)$ & 4.38 \\
Time taken for task (sec) & 46.76 & 22.95 \\
Number of correct responses in suppression task & $6.67(10)$ & 2.47 \\
Number of correct responses in fusion task & $6.91(10)$ & 2.55 \\
Short term memory & & \\
$\quad$ - right span & $5.91(8)$ & 1.91 \\
$\quad$ wrong span & $2.73(8)$ & 1.13 \\
Number of irregular words correctly written & $2.36(10)$ & 3.00 \\
Number of regular words correctly written & $6.06(10)$ & 2.81 \\
Number of pseudo words correctly written & $5.61(10)$ & 3.07 \\
\hline
\end{tabular}

a Number in parentheses is maximal score for each task.

Table 2. Means and standard deviations of the ODEDYS tests

\subsection{Measurements}

Children's Depression Inventory (CDI) (Kovacs, 2001)

CDI is a self-evaluation scale of depression for children and adolescents, 7 to 17 years old, elaborated by Kovacs in 1981. It has 27 items to specifically evaluate the different aspects of depression. Each item has three phrases, rated 0 to 2, to describe the increasing intensity of the depressive symptom. The child chooses the phrase that corresponds best to his state during the last 15 days (Bouvard et al., 2002). The global depression score is the sum of the scores of the 27 items. Global scores run from 0 to 54, higher scores representing more severe depression. CDI scores above 13 correspond to a moderate-severe depression (Greenham, 1999).

We chose this test for three reasons. First, it is often used in research about depression in children and adolescents. It may be the optimal measurement of depression in children and adolescents (Vella, Heath, \& Miezitis, 1992). Secondly, it is relatively short (27 items compared with 79 in MDI-C (Multiscore Depression Inventory for Children, Berndt \& Kaiser, 1999), which is also validated in French); as a result it is particularly well adapted for students with learning disabilities whose attention and concentration spans are quite limited. Finally, it has good psychometric characteristics (see Table 3 for comparison with alphas of Cronbach) and good retest reproducibility $(r=.82)$ after a period of one month (Finch, Saylor, Edwards, \& McIntosh, 1987). The validity of CDI has been confirmed by significant correlations with other methods of depression self-evaluation (Asarnow \& 
Carlson, 1985; Shain, Naylor, \& Alessi, 1990) and with ranking of depressive symptoms by clinical psychologists (Hodges \& Craighead, 1990; Shain and al., 1990).

\begin{tabular}{lccc}
\hline Subcategories & Our study & $\begin{array}{c}\text { Kovacs } \\
(2001)\end{array}$ & $\begin{array}{c}\text { French version of Lise } \\
\text { Saint-Laurent }\end{array}$ \\
\hline Pleasure & .60 & .66 & - \\
Negative mood & .48 & .62 & - \\
Feeling of inefficiency & .52 & .63 & - \\
Interpersonal problems & .71 & .59 & - \\
Negative self-esteem & .64 & .68 & .92 a \\
Global CDI & .85 & $.71-.89$ & \\
\hline
\end{tabular}

a after Cuillerier (2004)

Table 3. Cronbach's alphas of CDI by Kovacs (2001) from different studies

\section{Results}

\subsection{Level of depressive symptoms}

To compare the level of depression between dyslexic students and those in the control group, we performed an analysis of variance (ANOVA), using 2 (Group: dyslexics vs control) x 2 (Sex: girls vs boys) x 2 (Age: 8-10 vs 11-15 years old) as between-subjects variables with variable Group introduced as a fixed variable and the variables Sex and Age as covariates. The results show that there was no significant main effect of the variable Group $(F(1,62)=1.23, p>.05)$. There was no main effect of the variable Sex $(F<1)$ and the variable Age $(\mathrm{F}<1)$. The means and standard deviations are presented in Table 4.

\subsection{Prevalence of depressive symptoms in dyslexic children and adolescents}

Do dyslexic children and the control group have the same risk of depression? To answer this question, we analyzed the two groups by comparing the dimension of the severity of depression. One of the advantages of CDI scale is that it has normative references used by professionals to establish the clinical level of depression. Global CDI scores above 13 correspond to a moderate to severe depression. Table 4 shows means and SD of CDI scores for dyslexic and non-dyslexic children.

To evaluate the severity of depression in children, we reassigned the global score of depression a categorical value of 1 for CDI scores between 0 and 13, and 2 for scores over 13 . We thereby distinguished between weak and clinical cases of depression (i.e. moderate and severe). We then calculated percentages of children with weak and clinical levels of depression for each group. The results presented in Table 5 clearly show that in the group of dyslexic children $80 \%$ have weak levels of depression and $20 \%$ have moderate to severe levels. Results from the control group revealed that in children without dyslexia $97 \%$ had 
weak levels of depression and only 3\% had clinical levels. Separate chi-square tests for each group showed significant differences in the number of students with weak vs clinical levels of depression $(\mathrm{p}<.01)$.

\begin{tabular}{lcc}
\hline & $M$ & $S D$ \\
\hline Children with dyslexia $(n=35)$ & 8.74 & 7.24 \\
Children without dyslexia $(n=31)$ & 6.77 & 3.99 \\
\hline Girls $(n=29)$ & 7.14 & 5.19 \\
Boys $(n=37)$ & 8.35 & 6.55 \\
\hline $8-10$ year-olds $(n=34)$ & 8.44 & 6.80 \\
$11-15$ year-olds $(n=32)$ & 7.16 & 4.98 \\
\hline
\end{tabular}

Table 4. Means and standard deviations of depression scores as a function of group, sex and age.

\begin{tabular}{lcccc}
\hline & \multicolumn{2}{c}{$\begin{array}{c}\text { Dyslexics } \\
(n=35)\end{array}$} & \multicolumn{2}{c}{$\begin{array}{c}\text { Control group } \\
(n=31)\end{array}$} \\
\cline { 2 - 5 } & $\begin{array}{c}\text { Low level of } \\
\text { depression }\end{array}$ & $\begin{array}{c}\text { High level of } \\
\text { depression }\end{array}$ & $\begin{array}{c}\text { Low level of } \\
\text { depression }\end{array}$ & $\begin{array}{c}\text { High level of } \\
\text { depression }\end{array}$ \\
\hline \multirow{2}{*}{ Global CDI } & $80^{\mathrm{ac}}$ & $20 \mathrm{ad}$ & $97 \mathrm{bc}$ & 3 \\
\hline
\end{tabular}

$\mathrm{a}, \mathrm{b} p<.001$

${ }^{c} p<.05$

$\mathrm{d} p<.05$

Table 5. Percentage of students with low vs high levels of depression as a function of group

\section{Discussion}

The objective of our study was to compare the levels of depressive symptoms in dyslexic French-speaking students in specialized schools with students without dyslexia and to establish the prevalence of depressive symptoms in these dyslexic students. As mentioned in the introduction, relatively little research has been conducted to investigate depression in people with dyslexia. Their results are inconsistent. In addition, most of these studies have been carried out with English speakers. Nonetheless, educational systems and specialized educational structures differ from one country to the next. Furthermore, different languages offer intrinsically different levels of difficulty for people with dyslexia. The extremely irregular grapheme-to-phoneme correspondence (GPC) of English is quite an obstacle for students learning to read, and particularly so for dyslexic children (Seymour, Aro, \& Erskine, 2003). Even though French is classified as a language with irregular GPC, as noted earlier, it is more regular for reading than English.

The findings in this study suggest that global scores of depression appear to be the same for dyslexic children and the control group. These results are consistent with those found by Miller et al. (2005), who used CDI with children and adolescents from 6 to 16 years old. 
Their results are also similar to those found by Alexander-Passe (2006), who found no difference between dyslexic adolescents (14-16 years old) and those without dyslexia though using a different research methodology. The study by Willcutt and Pennington (2000) based on the comparison of twins with and without dyslexia revealed the same results. This last study is all the more valuable since Willcutt and Pennington used CDI to measure depression. Our study found no difference due to gender or age. As such, our results agree with those of Carroll et al. (2005) and de Miller and al. (2005).

In our study, no difference was found when average global scores of depressive symptoms were compared between student groups with and without dyslexia. Nonetheless, evaluation of the prevalence of those having clinical levels of depression showed that dyslexic students were much more susceptible to develop depression than students without dyslexia. Twenty percent of the dyslexic children and adolescents in our study had clinical levels of depression whereas 3\% did in the control group. As 10\% of the general population is considered to have clinical levels of depression (Greenham, 1999), this leads us to conclude that dyslexic students are more at risk of developing depression.

\subsection{Limitations and research perspective}

The first limitation of this study is its limited generalization. We have investigated depression level in dyslexic students going to a specialized school in French-speaking Switzerland. While these children may have severe levels of dyslexia (which justify their placement in this school), they are in a school environment that is well adapted for their disabilities. Scholastic expectations, rhythm and individual assistance are appropriate to meet their specific needs. In this school a medico-pedagogical team of specialized teachers, psychologists, and speech therapists accompanies each child and offers effective social support to both the student and parents.

When we consider the favorable context of the dyslexic students in our study, we are concerned about the psychological well-being, especially depression, of dyslexic students in integrated in traditional classes. Different systems of school integration for dyslexic students may offer different levels of support. A recent study of parents of Irish dyslexic children (Nugent, 2007) found that when schooling began these parents preferred integrating their children in traditional classes. Nonetheless, Nugent (2007) argued that their children would benefit from better schooling conditions in specialized schools. In Sweden, mothers of dyslexic students integrated in traditional classes emphasized that schools did not offer appropriate support for the needs of their children (Roll-Pettersson \& Mattson, 2007). Another study suggested that dyslexic students integrated in traditional classes in the Netherlands considered teachers and peers as threatening their self-esteem (Singer, 2007). Empirical evidence also supports specialized schooling. Butler and Marinov-Glassman (1994) concluded that with LD students' self-perception in specialized schools was more positive than that of students with LD in special classes or low-achieving students without LD. Burden (2005) found that specialized schools promote the psychological well-being of dyslexic students.

The conclusions of these studies lead us to be extremely prudent when making generalizations about dyslexic students from our findings. This limitation opens the 
perspective of intercultural research on the psychological well-being of dyslexic children as a function of different systems of school integration of these children in countries such France, Switzerland, Canada and Belgium. Research in this field until now has been limited to investigating self-esteem.

\subsection{Pedagogical and educational implications}

What recommendations and warnings can be drawn from the results of this study?

First, dyslexic children in a specialized school do not show more signs of emotional distress than students without dyslexia. As a group, regardless of age or sex, they are no more at risk of becoming depressed than peers without dyslexia.

Secondly, though as a group dyslexic students had a relatively low level of depression, the percentage of dyslexic students with clinical depression is significantly higher than that of the control group. This implies that parents and teachers must be attentive to these children's psychological well-being and wary of their slightest signs of distress. Adults must constantly be aware of the considerable individual differences within a group of dyslexic students. As risk factors and protection have not been studied much in dyslexic students, we can only conclude that these students are not all the same when facing psychological problems they may develop during their years of schooling. Though the current results showing no difference between dyslexic and non-dyslexic children may be reassuring, they must not be generalized for all dyslexic students, regardless of system of integration in school, nor even within a group of dyslexic students in the same system.

\section{Acknowledgments}

We would like to extend our gratitude to the direction of Institut Saint-Joseph in Fribourg (Switzerland), Mr. Noël and Ms. Savoy, as well as the medico-pedagogical team, whose open-minded and helpful attitude allowed us to complete this research. We would also like to sincerely thank the parents and children who participated in this study.

\section{References}

Alexander-Passe, N. (2006). How dyslexic teenagers cope: an investigation of self-esteem, coping and depression. Dyslexia, 12, pp. 256-275

Arnold, E.M., Goldston, D.B., \& Walsh, A.K. (2005). Severity of emotional and behavioural problems among poor and typical readers. Journal of Abnormal Child Psychology, 33, pp. 205-217

Asarnow, J.R., \& Carlson, G.A. (1985). Depression self-relating scale: Utility with child psychiatric inpatients. Journal of Consulting and Clinical Psychology, 53, pp. 491-499.

Beck, A.T., Steer, R.A., \& Brown, G.K. (1996). Beck Depression Inventory, The Psychological Corp: San Antonio

Bender, W.N., Rosenkrans, C.B., \& Crane, M. (1999). Stress, depression, and suicide among students with learning disabilities: Assessing the risk. Learning Disability Quarterly, 22, pp. 143-156

Billard, C., Fluss, J., Richard, G., Ziegler, J., Ecaille, J., Magnan, A. et al. (2007). Résultats préliminaires d'une étude épidémiologique transversale des apprentissages en lecture, 
orthographe et calcul au CE 1. Dyslexie, dysorthographie, dyscalculie: bilan des données scientifiques, Publications INSERM, Paris

Boetsch, E.A., Green, P.A., \& Pennington, B.F. (1996). Psychosocial correlates of dyslexia across the life-span. Development and Psychopathology, 8, pp. 539-562

Bouvard, M., Le Heuzey, M-F, Mouren-Simeoni, M-C, Abbou, H., Bange, F., Martin, C., Reneric, J-P, Saiag, M-C., \& Touzin, M. (2002). L'hyperactivité de l'enfance à l'âge adulte, Doin éditeurs, Rueil-Malmaison

Bruck, M., Genesee, F., \& Caravolas, M. (1997). A cross-linguistic study of early literacy acquisition. In: Foundations of reading acquisition and dyslexia: Implications for early intervention, Blachman, pp. 145-162, Erlbaum, Mahwah, NJ

Brumback, R.A., Dietz-Schmidt, S.G., \& Weinberg, W.A. (1977). Depression in children referred to an educational diagnostic center: Diagnosis and treatment and analysis of criteria and literature review. Disturbances of the Nervous System, 38, pp. 529-535

Burden, R. (2005). Dyslexia and self-concept, Whurr Publishers, London

Butler, R., \& Marinov-Glassman, D. (1994). The effects of educational placement and grade level on the self-perceptions of low achievers and students with learning disabilities. Journal of Learning Disabilities, 27, pp. 325-334

Carroll, J.M., Maughan, B., Goodman, R., \& Meltzer, H. (2005). Literacy difficulties and psychiatric disorders: Evidence for comorbidity. Journal of Child Psychology and Psychiatry, 46, pp. 524-532

Casey, R., Levy, S.E., Brown, K., \& Brooks-Gunn, J. (1992). Impaired emotional health in children with mild reading disability. Developmental and Behavioural Paediatrics, 13, pp. $256-260$

Chaix, Y., Trabanino, M., Taylor, M., \& Demonet, J.F. (2005). La dyslexie développementale: Apports récents de la génétique et de la neuro-imagerie, In Neuropsychologie de l'enfant et troubles du développement: Hommet, Jambaqué, Billard, \& Gillet, pp. 73101, SOLAL, Marseille

Colbert, P., Newman, B., Ney, P., \& Young, X. (1982). Learning disabilities as a symptom of depression in children. Journal of Learning Disabilities, 15, pp. 333-336

Cuillerier, L.M. (2004). Fiche sur l'inventaire de dépression pour enfant de Kovacs version candienne-française. Site sur les instruments psychométriques par l'Université McGill de Montréal. Vu le 20 décembre 2006

Dekker, M.C., Ferdinand, R.F., van Lang N., Bongers, I., van der Ende, J., \& Verhulst, F. (2007). Developmental trajectories of depressive symptoms from early childhood to late adolescence: gender differences and adult outcome. Journal of Child Psychology and Psychiatry, 48, pp. 657-666

Finch, A.J., Saylor, C.F., Edwards, G.L., \& McIntosh, J.A. (1987). Children's Depression Inventory: Reliability over repeated administrations. Journal of Clinical Child Psychology, 16, pp. 339-341

Frith, U. (1999). Paradoxes in the definition of dyslexia. Dyslexia, 5, pp. 192-214

Frith, U., Wimmer, H., \& Landerl, K. (1998). Differences in phonological recoding in German- and English-speaking children. Scientific Studies of Reading, 2, pp. 31-54

Goldstein, D., Paul, G.G., \& Sanfilippo-Cohen, S. (1985). Depression and achievement in subgroups of children with learning disabilities. Journal of Applied Developmental Psychology, 6, pp. 263-275 
Goldston, D. B., Walsch, A., Mayfield Arnold, E., Reboussion, B., Sergent Daniel, S., Erkanli, A., Nutter, D., Hickman, E., Palmes, G., Snider, E., \& Wood, F. B. (2007). Reading problems, psychiatric disorders, and functional impairment from mid- to late adolescence. Journal of American Academy of Child And Adolescent Psychiatry, 46, pp. $25-32$

Goodman, R. (2001). Psychometric properties of the Strengths and Difficulties Questionnaire (SDQ). Journal of the American Academy of Child and Adolescent Psychiatry, 40, pp. 1337-1345

Goswami, U. (2000). Phonological representations, reading development and dyslexia: Towards a cross-linguistic theoretical framework. Dyslexia, 6, pp. 133-151

Goswami, U., Gombert, J.E., \& Barrera, L.F. (1998). Children's orthographic representations and linguistic transparency: Nonsense word reading in English, French, and Spanish. Applied Psycholinguistics, 19, pp. 19-52

Greenham, S. L. (1999). Learning disabilities and psychosocial adjustment: A critical review. Child Neuropsychology, 5, pp. 171-196

Grigorenko, E. (2001). Developmental dyslexia: An update on genes, brains, and environments. Journal of Child Psychology and Psychiatry, 42, pp. 91-125

Hall, C.E., \& Haws, D. (1989). Depressive symptomatology in learning-disabled and nonlearning-disabled students. Psychology in the Schools, 26, pp. 263-275

Hasher, L., \& Zacks, R.T. (1979). Automatic and effortful processes in memory. Journal of Experimental Psychology: General, 108, pp. 356-388

Heiervang, E., Stevenson, J., Lund, A., \& Hugdahl, A. (2001). Behaviour problems in children with dyslexia. Nord Journal of Psychiatry, 55, pp. 251-256

Hinshaw, S.P. (1992). Externalizing behavior problems and academic underachievement in childhood and adolescence: causal relationships and underlying mechanisms. Psychological Bulletin, 111, pp. 127-155

Hodges, K., \& Craighead, W.E. (1990). Relationship of Children's Depression Inventory factors to diagnosed depression. Psychological Assessment, 2, pp. 489-492

Hoy, C., Gregg, N., Wisenbaker, J., Manglitz, E., King, M., \& Moreland, C. (1997). Depression and anxiety in two groups of adults with learning disabilities. Learning Disability Quarterly, 20, pp. 280-291

Hulme, C., \& Snowling, M. (1997). Dyslexia: Biology, cognition and intervention, Whurr Publishers, London.

Humphrey, N. (2002). Teacher and pupil ratings of self-esteem in developmental dyslexia. British Journal of Special Education, 29, pp. 29-36

Hunter-Carsch, M. (2001). Dyslexia. A psychosocial perspective. Whurr Publishers, London.

Hunter-Carsch, M., \& Herrington, M. (2001). Dyslexia and effective learning in secondary and tertiary education. Whurr Publishers, London.

Huntington, D.D., \& Bender, W.N. (1993). Adolescents with learning disabilities at risk? Emotional well-being, depression, suicide. Journal of Learning Disabilities, 26, pp. 159-166

Kline, C.L. (1986). The dyslexia-emotional dyad: implications for diagnosis and treatment. Canadian Journal of Psychiatry, 31, pp. 517-520

Kovacs, M. (2001). Children's depression inventory, Multi-Heath System, New York.

Lefavrais, P. (1967). Test de l'Alouette: Manuel, ECPA, Paris. 
Maag, J.W., \& Behrens, J.T. (1989). Depression and cognitive self-statements of learning disabled and seriously emotionally disturbed adolescents. The Journal of Special Education, 23, pp. 17-27

Maag, J.W., \& Reid, R. (2006). Depression among students with learning disabilities: Assessing the risk. Journal of Learning Disabilities, 39, pp. 3-10

Maughan, B., \& Carroll, J. (2006). Literacy and mental disorders. Current Opinion in Psychiatry, 19, pp. 350-354

Maughan, B., Rowe, R., Loeber, R., \& Stouthamer-Loeber, M. (2003). Reading problems and depressed mood. Journal of Abnormal Child Psychology, 31, pp. 219-229

Mayes, S., \& Calhoun, S. L. (2006). Frequency of reading, math, and writing disabilities children with clinical disorders. Learning and Individual Differences, 16, pp. 147-157

McNulty, M.A. (2003). Dyslexia and the life course. Journal of Learning Disabilities, 36, pp. 363-381

Miles, E. (2000). Dyslexia may show a different face in different languages. Dyslexia, 6, pp. 193-201

Miller, C. J., Hynd, G. W., \& Miller, S. R. (2005). Children with dyslexia : Not necessarily at risk for elevated internalizing symptoms. Reading and Writing, 18, pp. 425-436

Nugent, M. (2007). Comparing inclusive and segregated settings for children with dyslexia parental perspectives from Ireland. Support for Learning, 22, pp. 52-59

ODEDYS (2002). Laboratoire Cogni-Sciences IUFM de Grenoble. Web: http://www.grenoble.iufm.fr/recherch/cognisciences

Peck, M. (1985). Crisis intervention treatment with chronically and acutely suicidal adolescents. In Youth suicide, Peck, Farberow, \& Litman, pp. 112-122, Springer, New York.

Peereman, R., \& Content, A. (1999). LEXOP: A lexical database providing orthographyphonology statistics for French monosyllabic words. Behavior Research Methods, Instruments, and Computers, 31, pp. 376-379

Piccinelli, M., \& Wilkinson, G. (2000). Gender differences in depression. Critical review. British Journal of Psychiatry, 177, pp. 486-492

Prior, M., Smart, D., Sanson, A., \& Oberklaid, F. (1999). Relationships between learning difficulties and psychological problems in preadolescent children from a longitudinal sample. Journal of the American Academy of Child and Adolescent Psychiatry, 38, pp. 429-436

Reid, G., \& Fawcett, A. (2004). Dyslexia in context. Research, policy and practice, Whurr Publishers, London.

Reynolds, W.M. (1984). Depression in children and adolescents: Phenomenology, evaluation, and treatment. School Psychology Review, 13, pp. 171-182

Riddick, B. (1996). Living with dyslexia. The social and emotional consequences of special learning difficulties, Routledge, London.

Riddick, B., Sterling, C., Farmer, M., \& Morgan, S. (1999). Self-esteem and anxiety in the educational histories of adult dyslexic students. Dyslexia, 5, pp. 227-248

Rie, H.E. (1966). Depression in childhood: A survey of some pertinent contributions. Journal of the American Academy of Child Psychiatry, 5, pp. 653-685

Roll-Pettersson, L., \& Mattson, E. (2007). Perspectives of mothers of children with dyslectic difficulties concerning their encounters with school: a Swedish example. European Journal of Special Needs Education, 22, pp. 409-423 
Rourke, B.P. (1988). Socioemotional disturbances of learning disabled children. Journal of Consulting and Clinical Psychology, 56, pp. 801-810

Sanson, A., Prior, M., \& Smart, D. (1996). Reading disabilities with and without behaviour problems at 7-8 years: predicting from longitudinal data from infancy to 6 years. Journal of Child Psychology and Psychiatry, 37, pp. 529-541

Scott, R. (2004). Dyslexia and counselling, Whurr Publishers, London.

Seymour, P., Aro, M., \& Erskine, J. (2003). Foundation literacy acquisition in European orthographies. British Journal of Psychology, 94, pp. 143-174

Shain, B.N., Naylor, M., \& Alessi, N. (1990). Comparison of self-rated and clinician-rated measures of depression in adolescents. American Journal of Psychiatry, 147, pp. 793795

Sideridis, G., D. (2005). Goal orientation, academic achievement, and depression: Evidence in favour of a revised goal theory framework. Journal of Educational Psychology, 97, pp. 366-375

Sideridis, G.D. (2006). Understanding low achievement and depression in children with learning disabilities: A goal orientation approach. International Review of Research in Mental Retardation, 31, pp. 163-203

Sideridis, G., D. (2007). Why are students with LD depressed? A goal orientation model of depression vulnerability. Journal of Learning Disabilities, 40, pp. 526-539

Singer, E. (2007). Coping with academic failure, a study of Dutch children with dyslexia. Dyslexia, 14, pp. 314-333.

Sprenger-Charolles, L., \& Colé, P. (2003). Lecture et dyslexie : Approche cognitive, Dunod, Paris

Sprenger-Charolles, L., \& Serniclaes, W. (2003). Acquisition de la lecture et de l'écriture et dyslexie : revue de la littérature. Revue Française de Linguistique Appliquée, 1, pp. 6390

Stevenson, D.T., \& Romney, D.M. (1984). Depression in learning disabled children. Journal of Learning Disabilities, 17, pp. 579-582

Thomson, M. (1990). Dyslexia and Development. Whurr Publishers, London

Vella, D.D., Heath, N.L., \& Miezitis, S. (1992). Childhood depression assessment issues. In: Creating alternatives to depression in our schools: Assessment, intervention, prevention, Miezitis, pp. 95-106, Hogrefe and Huber, Toronto, ON

Wiener, J., \& Harris, P.J. (1993). Les relations sociales des sous-groupes d'enfants ayant des troubles d'apprentissage. Enfance, 47, pp. 295-316

Wiener, J., \& Tardif, C. (2004). Social and emotional functioning of children with learning disabilities: Does special education placement make a difference? Learning Disabilities: Research and Practice, 19, pp. 20-32

Willcutt, E.G., \& Pennington, B.F. (2000). Psychiatric comorbidity in children and adolescents with reading disability. Journal of Child Psychology and Psychiatry, 41, pp. 1039-1048

Wimmer, H., \& Goswami, U. (1994). The influence of orthographic consistency on reading development word recognition in English and German children. Cognition, 51, pp. 91-103

Wong, B. (Ed.) (2004). Learning about learning disabilities, Elsevier Academic Press, New York

Wong, B., \& Donahue, M. (2002). The social dimensions of learning disabilities, Lawrence Erlbaum Associates, Publishers, Mahwah, NJ 
Wong, D.A. (1985). The relationship between learning disabilities and depression in children. Unpublished doctoral dissertation, California School of Professional Psychology, Los Angeles

Wright-Strawderman, C., \& Watson, B.L. (1992). The prevalence of depressive symptoms in children with learning disabilities. Journal of Learning Disabilities, 25, pp. 258-264

Ziegler, J.C., \& Montant, M. (2005). L'apprentissage de la lecture dans différentes langues: un problème de taille. Le Langage et l'Homme, 12, pp. 149-160

Ziegler, J.C., Jacobs, A.M., \& Stone, G.O. (1996). Statistical analysis of the bidirectional inconsistency of spelling and sound in French. Behavior Research Methods, Instruments, and Computers, 28, pp. 504-515

Ziegler, J.C., Perry, C., Ma-Wyatt, A., Ladner, D., \& Schulte-Körne, G. (2003). Developmental dyslexia in different languages: Language-specific or universal? Journal of Experimental Child Psychology, 86, pp. 169-193 


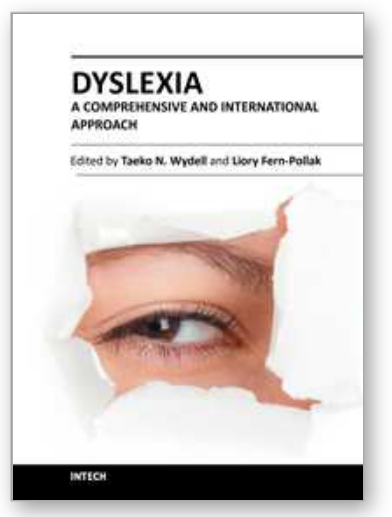

\author{
Dyslexia - A Comprehensive and International Approach \\ Edited by Prof. Taeko Wydell
}

ISBN 978-953-51-0517-6

Hard cover, 186 pages

Publisher InTech

Published online 18, April, 2012

Published in print edition April, 2012

This book brings together dyslexia research from different perspectives and from different parts of the world, with the aim of providing a valuable source of information to medical professionals specializing in paediatrics, audiology, psychiatry and neurology as well as general practitioners, to psychologists who specialise in developmental psychology, clinical psychology or educational psychology, to other professions such as school health professionals and educators, and to those who may be interested in research into developmental dyslexia. It provides a comprehensive overview of Developmental Dyslexia, its clinical presentation, pathophysiology and epidemiology, as well as detailed descriptions of particular aspects of the condition. It covers all aspects of the field from underlying aetiology to currently available, routinely used diagnostic tests and intervention strategies, and addresses important social, cultural and quality of life issues.

\title{
How to reference
}

In order to correctly reference this scholarly work, feel free to copy and paste the following:

Tamara Leonova (2012). Depression in Dyslexic Children Attending Specialized Schools: A Case of Switzerland, Dyslexia - A Comprehensive and International Approach, Prof. Taeko Wydell (Ed.), ISBN: 978953-51-0517-6, InTech, Available from: http://www.intechopen.com/books/dyslexia-a-comprehensive-andinternational-approach/depression-in-dyslexic-children-attending-specialized-schools

\section{INTECH}

open science | open minds

\author{
InTech Europe \\ University Campus STeP Ri \\ Slavka Krautzeka 83/A \\ 51000 Rijeka, Croatia \\ Phone: +385 (51) 770447 \\ Fax: +385 (51) 686166 \\ www.intechopen.com
}

\author{
InTech China \\ Unit 405, Office Block, Hotel Equatorial Shanghai \\ No.65, Yan An Road (West), Shanghai, 200040, China \\ 中国上海市延安西路65号上海国际贵都大饭店办公楼405单元 \\ Phone: +86-21-62489820 \\ Fax: +86-21-62489821
}


(C) 2012 The Author(s). Licensee IntechOpen. This is an open access article distributed under the terms of the Creative Commons Attribution 3.0 License, which permits unrestricted use, distribution, and reproduction in any medium, provided the original work is properly cited. 